\title{
Expert System to Determine Characteristics of Students With Special Needs With Forward Chaining Method
}

\begin{abstract}
$1^{\text {st }}$ Robby Rizky
Universitas Mathla'ul Anwar

Pandeglang, Banten, Indonesia

robby.rizky@unmabanten.ac.id

Abstract - Pandeglang is one of the disadvantaged areas in Banten Province. The regional original income in this city is very small compared to other cities in the Banten region. Here there are rarely human resources who do community service. This is due to the low regional minimum wage value. Therefore, an expert system was made to determine the character of special needs children. This requires a method-based, method step so that the completion step is proceeding properly. Forward chaining method is a method based on fitting rules in determining the character of students with special needs. This research contributes to teacher training in the field of counseling and computer science, especially in the field of expert systems.
\end{abstract}

Keywords-Expert System, Children Characteristic, SLB

\section{INTRODUCTION}

Nowadays the development of computers has undergone many very rapid changes, along with human needs that are increasingly numerous and complex. Computers are human aids in completing work. One reason why computers are more likely to be said to be human aids is that the speed and accuracy of the process are more reliable. Human desire to create something new which can help ease the burden of work constantly being done. This is because so many conveniences offered by computers, both in terms of accuracy and speed of information.

This encourages experts to increasingly develop computers in order to help human work or even exceed the ability of human work. Artificial intelligence or artificial intelligence is part of computer science that makes machines (computers) can do work as and as well as humans do. Intelligent systems (intelligent systems) are systems that are built using artificial intelligence techniques. Expert Systems are knowledge-based programs that provide expert quality solutions to problems in a specific domain. Expert systems are computer programs that mimic expert thought processes and knowledge in solving a particular problem. This type of program was first developed by artificial intelligence researchers in the 1960s and 1970s and was applied commercially during the 1980 s.

The development of science and technology is greatly influenced by globalization which brings positive changes in various fields of social life, development is science and technology in the form of computer development which was originally used as a calculation tool, but also as a tool to help solve problems and can display various information in data processing automatically.

Another example of the field of artificial intelligence development is an expert system that combines knowledge and data tracking to solve problems that normally require human expertise. The purpose of developing expert systems is actually not to replace the role of humans, but to substitute human knowledge in the form of systems, so that it can be used by many people.

- Problem formulation-This research contributes to the science of education and to computer scientists, especially in the field of expert systems, in this study also contributes to the view of schools that have difficulty in getting teacher guidance counseling, this expert system can help these problems.

- Limitation of the problem-This study only discusses the characteristics of services, with a forward chaining methodology approach.

- $\quad$ Research Functions and Objectives-The function of this study is to determine the character of students in SLB schools, because determining the character of students with special needs is more difficult than with normal students in general.

\section{METHOD}

In this study using the forward chaining methodology approach the reason using the forward chaining approach is based on the rules studied.

\section{A. Characteristics}

In early childhood character education books [2] Look at the character refers to a series of attitudes, (behaviors), (motivation), and (skills). The real character comes from Greek which means "to mark" or "marking", and focus on how to apply the value of goodness in the form of actions or behavior. Character is the character, character, character, or personality of a person that is formed from the internalization of various virtues that are believed and used as a basis for perspective, thinking, and acting. 


\section{B. Inference Mechanism}

Inference theory is part of an expert system that makes reasoning by using the contents of a list of rules based on a certain sequence and pattern. During the consultation process between systems and users, the inference mechanism tests the rules one by one until the conditions are correct.

In general, there are two main techniques used in the inference mechanism for testing rules, those are forward chaining and backward chaining.

\section{Forward Chaining}

In advanced reasoning, the rules are tested one by one in a certain order. The sequence may be the order in which rules are entered into the rule base or also other sequences specified by the user. When each rule is tested, the expert system will evaluate whether the condition is wrong or wrong. If the conditions are right, then the rule is saved then the next rule is tested. Conversely, if the condition is wrong, the rule is not saved and the next rule.

\section{Backward Chaining}

It is the reasoning of a set of hypotheses towards the supporting facts, so the tracking process starts backwards by determining the conclusions to be sought and then the facts of the conclusion builders.

\section{RESULTS AND DISCUSSION}

Knowledge representation with rules is often called a production system. One rule consists of 2 (two) parts, i.e.:

A. Antocedent that is the part that expresses a situation or premise (knowledge begins with IF)

Consequent is the part that says a certain action or conclusion is applied if the situation or premise is true (statement starts with THEN). Inference with rules (as well as logic can be effective, but there are some limitations on certain techniques

B. Expert system

Expert systems are computer-based applications that are used to solve problems as thought by experts
(Kusrini, 2008). The experts referred to here are people who have special expertise who can solve problems that cannot be solved by ordinary people.

In its preparation, the expert system combines inference rules with certain knowledge bases provided by one or more experts in a particular field. The combination of these two things is stored in a computer, which is then used in the decision making process for solving certain problems.

The development of expert systems aims to implement expert knowledge on software that can be used easily by users (Istiqoma and Fadlil, 2013). To build an expert system, several basic components are needed: Knowledge Base; Inference Machine; Database; User Interface.

The explanation of the basic components to build an expert system (Hu and friends, 1987):

1) Knowledge Base

The knowledge base is a representation of an expert, which can then be entered into a specific programming language for artificial intelligence (for example PROLOG or LISP) or expert system shells (for example EXSYS, PC-PLUS, CRYSTAL, etc.)

2) Inference Engine

The inference engine functions to guide the reasoning process for a condition, based on the available knowledge base. In the inference engine there is a process to manipulate and direct the rules, models, and facts stored in the knowledge base in order to reach a solution or conclusion.

3) Database

The database is used to store data from observations and other data needed during processing.

4) User Interface

This facility is used as an intermediary for communication between the user and the system. Comparison between the capabilities of human expert systems and computer systems which are considered as expert systems development.

Table 1. Comparison of Expert and Computer Systems

\begin{tabular}{ll}
\hline \multicolumn{1}{c}{ Human Expert } & \multicolumn{1}{c}{ Expert System } \\
\hline Limited time because human need rest & Unlimited because it can be used at any time \\
The place of acces is local at any place where the expert & Can be used in various places \\
Knowledge is variable and can change depending on the situation & Knowledge is consistent \\
The speed to find solution is diverse & The speed to provide solution is consistent and \\
& faster that humans \\
The fee that must be paid for consultation is very expensive & Cost incurred are cheaper \\
\hline
\end{tabular}

In addition to the many benefits obtained, the weakness of expert system development is:

- Manpower and productivity are reduced because everything is done automatically by the system.
- Developing expert system software is more difficult than conventional software.

- This can be seen from the following comparison table 2 . 
Table 2. Comparison of Conventional Software and Expert System Software

Conventional software Expert system Software

Focus on solutions

Development can be done individually

Sequential development

\section{Children with Special Needs}

The concept of children with special needs has a broader meaning compared to the understanding of extraordinary children. Children with special needs are children who in education need specific services, different from children in general. Children with special needs are experiencing obstacles in learning and development. Therefore, these children need services that are suited to the learning needs of each child. In general, the range of children with special needs includes two categories, namely: children with special needs who are permanent, namely the result of certain disorders and children with special needs that are temporary, that is, children who experience learning and development barriers caused by environmental conditions and situations. Every child with special needs, both permanent and temporary, has different learning constraints and learning needs.

2) Results and Review
Focus on the problem.

Development is carried out by teamwork

Iterative development.
Learning barriers experienced by every child are caused by three things: Environmental factors; Children internal factors; The combination of environmental and internal factors.

Every child with special needs has certain characteristics that are different from another, children included in the special needs category, among others: visually impaired, deaf, mentally retarded, blind, disabled, learning difficulties, slow learning, autistic children, gifted children and hyperactive children. (Delphie, 2009).

\section{1) Engineering Knowledge}

The conversion of production rules into a decision table for children with special needs can be seen in table 1. Rows indicate characteristics and columns indicate types of special needs children.

Table 3. Decisions to Diagnose Characteristics of Children With Special Needs

Data feature $\quad \begin{array}{llllllllll}1 & 2 & 3 & 4 & 5 & 6 & 7 & 8 & 9 & 10\end{array}$

Poor or uncontrolled movement coordination $\sqrt{ }$

The fingers are stiff and cannot hold

There are parts of the limbs that are incomplete

Difficulty in movement

There are defects in the limbs

Often skiping class

Difficulty differentlating forms

Often make mistakes in reading 
Table 4. Decision to diagnose characteristics of children with special needs (continued)

The catch is slow

Never skipped class

Difficulty in recognizing and respon

Rigidity and poor in expressing feeling

Lack of feeling and empathy

Not easily satisfied with the achievements

Often annoying friends inclass.

Having difficulty in concentrating on doing school work

Not easily satisfied with the achievements he achieved $\sqrt{ }$

$\sqrt{ }$

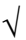

$\sqrt{ }$

$\sqrt{ }$

$\sqrt{ }$

$\sqrt{ }$

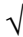

In this study, the types or characters of children with special needs are divided into 10 types, as shown in table 5.

Table 5. Type of Children with Special Needs

\begin{tabular}{llll}
\hline No & Kode & \multicolumn{1}{c}{ Type } \\
\hline & ABK 01 & Children with visual impairment \\
2 & ABK 02 & Children with hearing loss \\
3 & ABK 03 & Children with intellectual disorders \\
4 & ABK 04 & Children with limb disorders \\
5 & ABK 05 & Children with behavioral and emotional \\
6 & ABK 06 & Children with specific learning difficulties \\
7 & ABK 07 & Slow learning children \\
8 & ABK 08 & Autistic child \\
9 & ABK 09 & Talented kid \\
10 & ABK 10 & Hyperactive child \\
& & \\
\hline
\end{tabular}

\section{CONCLUSION}

Based on an expert system analysis diagnosing the characteristics of special needs children using the forward chaining method, it can be concluded as follows:

1. Expert system diagnoses the characteristics of special needs children using the forward chaining method to make it easier to find out the characteristics of children and provide solutions to problems determining the characteristics of special needs (ABK).

2. This research produces an expert system algorithm to determine the characteristics of children with special needs.

\section{REFERENCES}

[1] Delphie, Bandi, M.A, S.E, Dr, Prof. 2009 PembelajaranAnakBerkebutuhanKhususDalam Setting PendidikanInklusi.Klaten: IntanSejati

[2] Handayani, L., \&Sutikno, T. (2008).SistemPakaruntuk Diagnosis Penyakit THT Berbasis Web dengan "e2gLite Expert System Shell".JurnalTeknologiIndustri, 12(1), 19-26.

[3] Istiqomah, Y.N. \&Fadlil, 2013.SistemPakaruntukMendiagnosaPenyakitSaluranPencernaan menggunakanMetodeDempster

Shafer.JurnalSarjanaTeknikInformatika, 1(1).

[4] Handojo, MPH. 2003.Autisme

(PetunjukPraktisdanPedomanMateriUntukMengajar, Anak Normal, AutisdanPrilaku Lain). Jakarta

[5] Kusrini, S.Kom. 2006. SistemPakar, TeoridanAplikasi. Yogyakarta: Andi.

[6] Rohman, FeriFahrur, and Ami Fauzijah."Rancangbangunaplikasisistempakaruntukmenentukanj enisgangguanperkembanganpadaanak."Media Informatika6.1 (2008). 
[7] Sunyoto, Andi. 2007. Pemrograman Database dengan Visual Basic dan Microsoft SQL. Yogyakarta: Andi.

[8] Tim Penerbit 2009.

PengembanganSistemPakarmenggunakan Visual

Basic. Yogyakarta: Andi. 